\title{
Local plant species replace initially sown species on roadsides in the Swiss National Park
}

\author{
Sabine Güsewell \& Frank Klötzli
}

Keywords: disturbance, neophytes, road construction, restoration, succession, Swiss National Park

\section{Abstract}

Protected areas in the Alps are dissected by high-traffic roads for tourist access and transit. Road construction leaves disturbed areas with open soil, which may serve as starting points for the invasion of alien plants or ruderal lowland plants into the protected mountain habitats. In the 1960s, a transit road was widened in the Swiss National Park (SNP) and disturbed roadsides were sown with mixtures of grassland species. Roadside development and vegetation dynamics in the adjacent subalpine pine (Pinus mugo) forest were monitored in permanent plots from 1969 till 2010. Over the 42-year monitoring period, the sown species disappeared progressively and were replaced by species from naturally disturbed areas as well as by forest species. A standard seed mixture and native seeds introduced with local hay developed similarly. Sown species did not expand into the natural habitats and no alien species colonized the roadsides, despite the long-term persistence of open soil. The impact of roadsides on the local flora was therefore minimal. Ecological indicator values suggest that the development of roadsides in the SNP was determined by harsh conditions resulting from a continental subalpine climate and poorly developed soils on dolomite. Therefore, the developments observed in the SNP and the proposed low impact of roadsides on the natural vegetation may not hold for other Alpine regions with different geology and a more oceanic climate.
Profile

Protected Area

Swiss National Park

Mountain range

Alps

Country

Switzerland

\section{Introduction}

Protected areas in the Alps are dissected by hightraffic roads for tourist access and transit. Road construction in mountains requires severe physical disturbance to create a flat roadbed. The resulting cut and fill slopes exhibit bare soils, usually with a high proportion of rock or gravel, little organic matter, poor water retention and low nutrient availability (Paiaro et al. 2011). For aesthetic or conservational reasons and to reduce soil erosion, roadsides are often sown with grassland species, which should rapidly cover the open areas, promote soil development and initiate the succession towards more natural vegetation (Tikka et al. 2000; de la Riva et al. 2011; Mola et al. 2011). However, reseeding is expensive, especially if it is to be done with local species (Bochet et al. 2010). Furthermore, the treatment may be ineffective, either because sown species fail to get established or because some of the sown species grow successfully and even spread into the natural habitats but do not facilitate the establishment of local species (Matesanz et al. 2006; de la Riva et al. 2011; Mola et al. 2011).

If road construction sites are left to natural succession, species from surrounding habitats may establish and build new, site-specific plant communities (Bochet et al. 2007; Karim \& Mallik 2008). However, species immigration from natural vegetation may be slow and colonizing species may be primarily ruderal species from the lowlands as well as invasive alien species (Rentch et al. 2005; Takahashi \& Miyajim 2010).
Roads are known worldwide as starting points for the invasion of alien species, the propagules of which are imported by cars and visitors (Rentch et al. 2005; von der Lippe \& Kowarik 2007; Sharma \& Raghubanshi 2009). Exotic species, which often have a ruderal life strategy, also tend to benefit more than native species from improved light conditions along roads (Flory \& Clay 2009). Decisions about the restoration of roadsides after construction work therefore need to consider several aspects: aesthetic needs for rapid regrowth, risks of soil erosion, opportunities for natural succession and risks of plant invasions.

The SNP, founded in 1914, is crossed by a transit road linking the Engadine valley to the Mustair valley over the mountain pass Ofenpass (Figure 1a). The road was rebuilt and expanded in the 1960s. Construction work involved forest clearing and slope cutting, leaving bare rocky soil and gravelly fill areas along the road. Fill areas were reseeded in late summer 1968, either with a standard seed mixture or through hay transfer.

To fulfil the research and monitoring mandate specified in the foundation document of the SNP, a monitoring programme started in 1969 to observe the development of the sown roadside communities as well as adjacent forest vegetation (Klötzli 1991). Permanent plots established on roadsides and in adjacent forest stands were surveyed 11 times in total between 1969 and 2010 to determine whether (1) the sown species became established on the roadsides, (2) species from surrounding natural habitats spontaneously colonized the roadsides, (3) roadside species spread into 


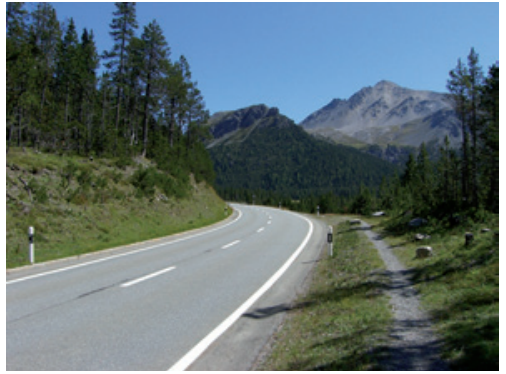

(a) Ofenpass road near Buffalora $(1900 \mathrm{~m})$

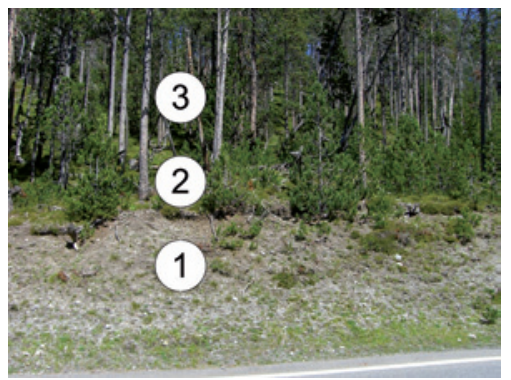

(d) The three plot types: 1. roadside, 2. forest edge and 3. forest

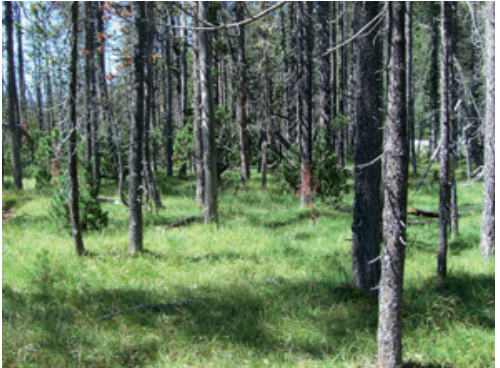

(b) Natural mountain pine (Pinus mugo) forest with dense herb layer

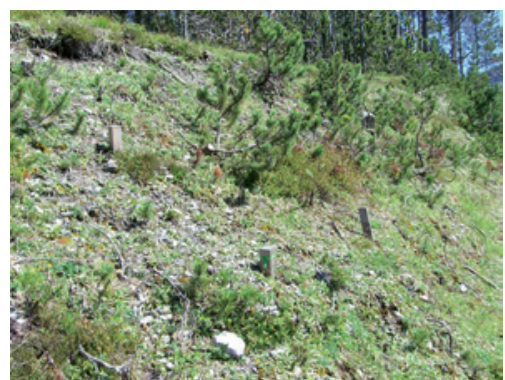

(e) Permanent plot, delimited by wooden pickets.

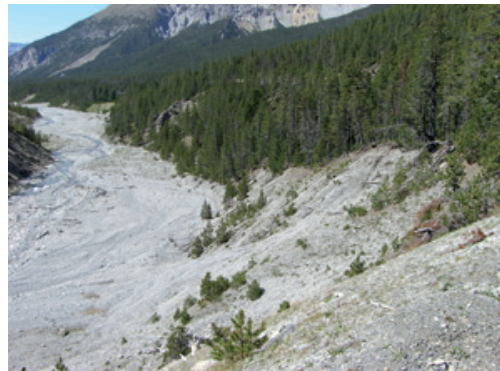

(c) Natural calcareous scree babitats on erosion slopes and in river beds; adjacent forests, and (4) species from the lowlands or alien species colonized the roadsides. While the second trend was particularly desirable with respect to the conservation aims of the SNP (promote natural ecosystem dynamics), the third and fourth trend would indicate that roadsides promote the establishment of non-native species in the protected area.

Vegetation development during the first 19 years (1968-1987) mainly revealed the second trend: species from the surroundings started to colonize the roadsides, whereas most of the sown species established themselves only poorly and hardly occurred outside the sown areas (Klötzli 1991). Here we analyse vegetation development over 42 years $(1968-2010)$ to see whether trends observed until 1987 persisted over a longer period of time and to examine possible reasons for these developments.

\section{Material and methods}

\section{Site description}

The Ofenpass road (Figure 1a, Figure 2) runs from Zernez $(1471 \mathrm{~m})$ in the Engadine valley to Sta Maria $(1375 \mathrm{~m})$ in the Mustair valley (South-Eastern Swiss Alps). The highest point is Ofenpass $(2149 \mathrm{~m})$. The total length of the road is approximately $66 \mathrm{~km}$, of which $13 \mathrm{~km}$ lie within the perimeter of the SNP. The altitude of the road section within the SNP ranges from $1711 \mathrm{~m}$ (Punt la Drossa) to $1968 \mathrm{~m}$ (Buffalora). Coordinates of the central point of this road section are $46^{\circ} 40^{\prime} \mathrm{N}$ and $10^{\circ} 12^{\prime} \mathrm{E}$.

The geological background is calcareous rock and soils are mostly poorly developed rendzinas. The vegetation along the Ofenpass Road is subalpine mountain pine (Pinus mugo) forest with an open canopy and a well-developed herb layer dominated by graminoids and dwarf shrubs (Figure 1b). Naturally disturbed areas, such as active erosion slopes, avalanche runs and river beds, harbour a sparse calcareous scree vegetation with perennial forbs, small sedges, lichens, dwarf shrubs and mountain pine seedlings (Figure 1c). Locally, there are small grassland areas maintained by deer grazing; there is no agricultural land use within the SNP.

Reseeding of bare ground left after road construction work took place in August 1968. Some sections were hydroseeded using a standard seed mixture of meadow grasses and legumes, and some sections were seeded using fresh hay from mountain meadows in the Mustair valley as a source of seeds from the regional genetic pool (Table 1).

\section{Data collection}

For monitoring roadsides, ten sites with cut slopes or embankments of at least $5 \mathrm{~m}$ width were located along the road section within the SNP. At each site, two or three permanent plots $\left(1 \mathrm{~m}^{2}\right)$ were established in 1969 (Figure 1d): one or two plots at the roadside (in the middle of the disturbed slope); one plot within the forest, at a place with well-developed, undisturbed herb layer, $10-20 \mathrm{~m}$ away from the road. At sites where a new forest edge had been created, one plot was added at about $3 \mathrm{~m}$ from the forest edge, where the colonization of roadside species or other adverse effects of roads were most likely to occur. The small number and size of permanent plots was chosen in 1969 to facilitate long-term monitoring while minimizing the disturbance caused by survey work.

Plots were delimited with wooden pickets (Figure 1e) and surveyed in 1969, 1970, 1972, 1974, 1977, 


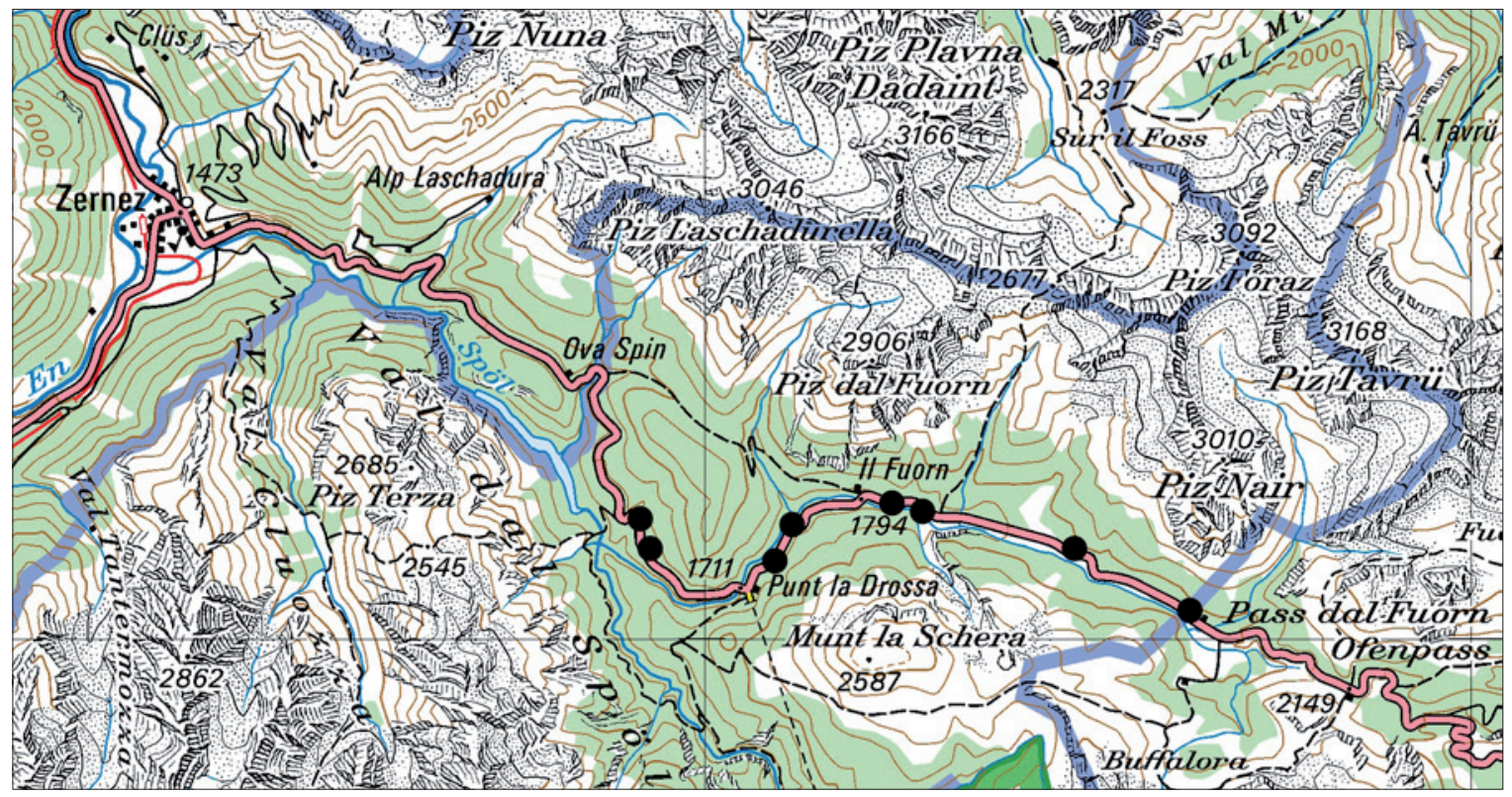

Figure 2 - Map of the study area in the Eastern Swiss Alps, with the Ofenpass road in red, the boundary of the SNP in blue and the eight study sites remaining by 2010 as black dots. Source: Bundesamt für Landestopografie swisstopo (Art. 30 GeoIV): 5704000000

1979, 1983, 1987, 2002, 2003 and 2010. Surveys were generally carried out in August, when vegetation development was at its peak. Some study sites were located on cut slopes (uphill side), and some on embankments (downhill side), but, consistent with other studies (e.g. Rentch et al. 2005), no difference between these locations was apparent. Therefore, the two topographic positions were not distinguished any further.

Species composition was always recorded on the Braun-Blanquet dominance-abundance scale $(r,+, 1$, $2,3,4,5)$, separately for the moss, herb, shrub and tree layer. Cryptogams were identified to the genus. Species nomenclature changed over time. After the final survey in 2010, species names were adjusted to the nomenclature of Lauber \& Wagner (2007), using the Swiss index of synonymy (Aeschimann \& Heitz 2005) where necessary. The total percentage cover of each vegetation layer was also estimated visually.

Because the small size of the survey plots increased the probability of missing some species, we also recorded species presences within a radius of about $3 \mathrm{~m}$ around the plots. These additional data were not analysed but used to check statements about the absence of certain species groups (e.g. absence of alien species on roadsides or absence of sown species in forests).

Two of the sites were destroyed between 1987 and 2002 by a landslide and by new construction work, respectively. In addition, data from 1969-1987 only remained available for four sites. Overall, 160 relevés were available for data analysis, of which different subsets were used in individual analyses. Long-term vegetation development in individual plots was analysed for the four sites with data available back to 1969. Recent vegetation development was analysed for the eight sites remaining in 2010 (Figure 2).
Data analysis

Data analysis was based on plant species recorded in the herb and shrub layer; the tree layer was excluded. Braun-Blanquet codes of + and $r$ were transformed into 0.5 and 0.2 , respectively. The numeric codes were

Table 1 - Species sown on the roadsides in 1968, either within a standard seed mixture (source: unpublished anonymous report from 1968, composition given as percentages) or with hay from nearby mountain meadows (species that occurred in at least two of the plots seeded with hay in 1969-1970).

\begin{tabular}{|l|r|r|}
\hline Species & Seed mixture & Hay \\
\hline Achillea millefolium & & $\mathrm{x}$ \\
\hline Agrostis stolonifera & $20 \%$ & $\mathrm{x}$ \\
\hline Alchemilla vulgaris & & $\mathrm{x}$ \\
\hline Briza media & $3 \%$ & $\mathrm{x}$ \\
\hline Carum carvi & & $\mathrm{x}$ \\
\hline Cerastium arvense & $5 \%$ & $\mathrm{x}$ \\
\hline Cynosurus cristatus & $10 \%$ & $\mathrm{x}$ \\
\hline Dactylis glomerata & $10 \%$ & $\mathrm{x}$ \\
\hline Elymus repens & & $\mathrm{x}$ \\
\hline Festuca ovina & $12 \%$ & $\mathrm{x}$ \\
\hline Festuca rubra & & $\mathrm{x}$ \\
\hline Leucanthemum adustum & & $\mathrm{x}$ \\
\hline Linum catharticum & $10 \%$ & $\mathrm{x}$ \\
\hline Lolium perenne & $5 \%$ & $\mathrm{x}$ \\
\hline Lotus corniculatus & $5 \%$ & $\mathrm{x}$ \\
\hline Medicago lupulina & & $\mathrm{x}$ \\
\hline Plantago lanceolata & & \\
\hline Plantago media & & \\
\hline Poa pratensis & & \\
\hline Ranunculus montanus & & \\
\hline Taraxacum officinale & & \\
\hline Trifolium badium & & \\
\hline Trifolium incarnatum & & \\
\hline Trifolium hybridum & & \\
\hline Trifolium pratense & & \\
\hline
\end{tabular}


further square-root transformed to reduce the influence of dominant species on the analysis.

Changes in vegetation composition were described with principal coordinates analysis based on a distance matrix with Bray-Curtis distances, after excluding species found only in one or two relevés. Floristic similarities between plots of the same type (roadside, forest edge, forest) and between plots of different types were derived from the Bray-Curtis distance matrix for each year of the study (similarity $=1$-distance). Means and standard errors of similarities were calculated for all pairs of relevés belonging to the respective type(s) in the relevant year.

Ecological indicator values of the vegetation, the affinity of plant communities to habitat types and biogeographic status were analysed using information from Landolt et al. (2010). This database contains regional indicator values for the flora of Switzerland and the Alps, the habitat types in which species occur, as well as their biogeographic status for Switzerland and the Alps (native, introduced before 1500 or introduced after 1500). For closely related taxa (microspecies, e.g. regional forms or ecotypes), ecological indicator values are also provided for species aggregates, provided that all microspecies within the aggregate exhibit a similar behaviour. Habitat types are listed for each microspecies, so that many habitat types can be associated with each aggregate.

Many taxa treated as aggregates in Landolt et al. (2010) used to be treated as a single species in earlier floristic literature (Lauber \& Wagner 2007) and were recorded as single species in this study. In such cases (47 taxa), indicator values of the aggregates were used unless species records could be unequivocally assigned to one microspecies. The calculation of average indicator values for each ecological factor was therefore based on the subset of taxa for which this information was available ( $81-96 \%$ of the taxa). Weighted averages were calculated, using square-root transformed species cover as weights.

To determine the affinity of plant communities to particular habitat types, all habitat types associated with each species or aggregate (Landolt et al. 2010) were taken into account. The species or aggregate was given a score of 1 or 0 for each of four habitat classes, depending on whether or not it occurs in such habitats: forest, alpine grasslands, natural pioneer habitats (rocks and scree, riverbeds) and ruderal lowland habitats (constructed areas, crop fields, spoil areas, roads and pathways etc.). These are the habitat types naturally occurring in the lower part of the SNP as well as possible source habitats for new colonizers. Each species could be given between 0 and 4 scores of ' 1 ', i.e. scores were not adjusted to a sum of 1 within species. The affinity of a relevé to each habitat type was calculated as the proportion of species or aggregates that can occur in this habitat type.

Long-term changes in species richness and ecological indices were described in graphs; no statistical test was applied given the small number of plots. To analyse recent differences in species richness and ecological indices between roadsides and forested plots, data from 2002-2010 were first averaged for each individual plot. Then, roadside plots were compared to forested plots with analyses of variance based on mixed models with plot type as fixed effect and site as random effect. In this analysis, forested plots include both normal forest plots and forest-edge plots (located within the forest, but near the edge); these plot types were pooled to increase statistical power since an initial analysis revealed no significant differences between forest and forest-edge plots.

\section{Results}

\section{Vegetation structure}

A total of 214 plant species were recorded in the 160 relevés. Of these, 88 species were found only on roadsides, 33 only in forest or forest edge vegetation, and 93 in both types of habitats. All species were native to Switzerland or the Alpine region.

The number of sown species (as seed mixture or through hay transfer) decreased throughout the study period (1969-2010) on roadsides, while remaining constantly low in the forest and forest edge plots (Figure $3 \mathrm{a}, \mathrm{b})$. The total number of vascular plant species varied considerably among plots, without clear temporal trend (Figure 3c). In 2002-2010, the number of species sown as seed mixture and the total number of vascular plant species did not differ significantly between roadsides and forested plots, while the number of species sown through hay transfer was significantly higher on roadsides (Table $2 \mathrm{a}$ ).

The average cover of herbaceous plants (sum of moss and herb layer) in 2002-2010 was 56\% on roadsides and $85 \%$ in forest edge or forest plots. The average cover of woody plants (sum of shrub and tree layer) was $11 \%$ on roadsides and $14 \%$ in forest edge or forest plots.

\section{Species composition}

Roadside vegetation was clearly distinct from the neighbouring forest vegetation throughout the study period, although the difference diminished over time. In the ordination of vegetation relevés from $1969-2010$ (Figure 4a), the first ordination axis $(31.5 \%$ of variation) separated the roadside relevés from the forest edge and forest relevés. Species strongly associated with roadside relevés were typical of lowland or mountain meadows, while forest relevés were characterized by the typical herb layer of subalpine coniferous forests (Table 3). Over time, most roadside relevés became slightly more similar to forest vegetation, as indicated by a rightward shift along the first ordination axis (Figure 4a).

The second ordination axis (8.5\% of variation) separated the roadside plots restored through hay application from those sown with a standard seed mix- 
(a) Species in seed mixture

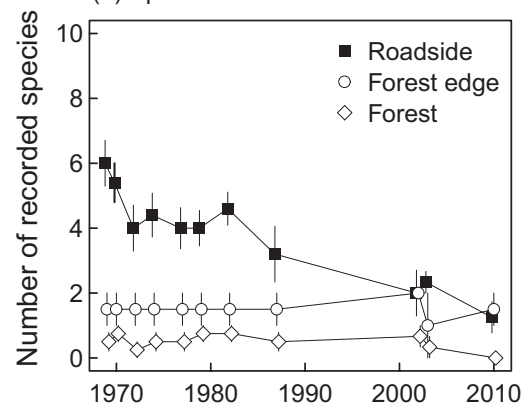

(b) Species in hay

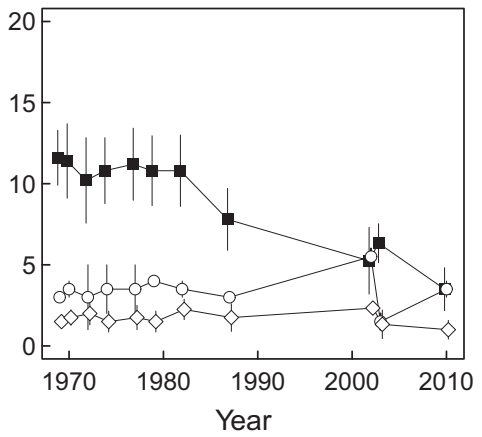

(c) All vascular plant species

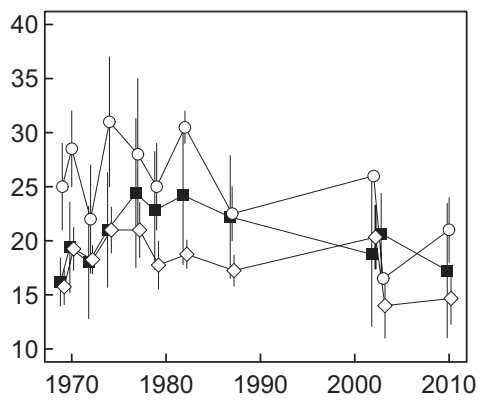

Figure 3 - Numbers of vascular plant species recorded in the three types of plots (roadside, forest edge, forest) in each monitoring year (1969-2010): (a) species included in the seed mixture, (b) species introduced through hay transfer, and (c) all vascular plant species. Graphs show means \pm s.e. per plot type and year; $n=4$ (roadside), 2 (forest edge) and 3 (forest). All plots are represented in each panel, regardless of their seeding treatment, i.e. species numbers in (a) and (b) include populations that were introduced by seeding as well as populations of the same species that established spontaneously

ture (Figure 4a). This separation persisted until 2010, except for one hay plot, which became similar to sown plots by 2002. Among forest plots, there was also a gradient along the second ordination axis from northfacing plots with species typical of mesic, slightly acidic soils, to south-facing plots with species typical of dry, calcareous soils.

The ordination of all relevés from 2002-2010 also shows a clear separation between roadside and forest vegetation along the first ordination axis (Figure 4b). Forest relevés were characterized by the same species as in the long-term data series, whereas roadside relevés were characterized by species from dry alpine grasslands and natural pioneer vegetation (Table 3 ). The second ordination axis separated one moist, north-facing roadside plot with species such as Pinguicula vulgaris, Geranium sylvaticum, Alchemilla vulgaris etc. from the other roadside plots, with frequent occurrence of Leontodon hispidus, Hieracium staticifolium, Viola rupestris, Polygala amarella etc.

Patterns apparent in ordination plots were confirmed by the calculation of mean similarity indices (Figure 5). The forest and forest edge relevés always resembled each other, with a mean similarity of $40-60 \%$ throughout the study period (Figure 5a). The similarity between forest and forest edge relevés did not decrease over time (Figure 5b), i.e. the species composition of potentially disturbed forest edges did not shift away from that of undisturbed forest. Roadside relevés were less similar to each other than forest relevés (mean similarity of $30-40 \%$ ), and their similarity further decreased over time (Figure 5a). Concomitantly, roadside relevés became slightly more similar to forest and forest edge relevés (Figure 5b).

Table 2 - Comparison of vegetation properties between roadsides and forested plots (forest and forest edge plots pooled). Data from 2002-2010 were first averaged for each individual plot. Then, roadside plots were compared to the forested plots with analyses of variance including sites as random effects. The last column describes qualitatively how roadsides differ from forested plots (ns $=$ no significant difference).

\begin{tabular}{|c|c|c|c|c|c|}
\hline & Roadside $(n=8)$ & Forested $(n=9)$ & $F$ value & $p$ value & road vs. forest \\
\hline \multicolumn{6}{|c|}{ (a) Species numbers ${ }^{1}$} \\
\hline In seed mixture & $1.31 \pm 0.35$ & $0.80 \pm 0.19$ & 1.82 & 0.214 & ns \\
\hline In hay & $3.79 \pm 0.92$ & $1.65 \pm 0.41$ & 5.57 & 0.046 & higher \\
\hline All vascular plants & $19.17 \pm 3.79$ & $16.80 \pm 1.56$ & 0.56 & 0.476 & ns \\
\hline \multicolumn{6}{|c|}{ (b) Mean ecological indicator values of the vegetation } \\
\hline Temperature & $2.59 \pm 0.08$ & $2.47 \pm 0.05$ & 1.763 & 0.221 & ns \\
\hline Continentality & $3.50 \pm 0.04$ & $3.46 \pm 0.03$ & 0.574 & 0.470 & ns \\
\hline Light & $3.77 \pm 0.06$ & $3.23 \pm 0.07$ & 49.964 & $<0.001$ & higher \\
\hline Soil moisture & $2.27 \pm 0.11$ & $2.47 \pm 0.06$ & 5.243 & 0.051 & $\mathrm{~ns}$ \\
\hline Soil pH & $3.48 \pm 0.05$ & $3.29 \pm 0.07$ & 5.239 & 0.051 & ns \\
\hline Nutrients & $2.15 \pm 0.09$ & $2.04 \pm 0.02$ & 1.605 & 0.229 & ns \\
\hline Salinity & $0.20 \pm 0.03$ & $0.09 \pm 0.02$ & 13.404 & 0.006 & higher \\
\hline \multicolumn{6}{|c|}{ (c) Affinities to vegetation types ${ }^{2}$} \\
\hline Forest & $0.66 \pm 0.05$ & $0.86 \pm 0.03$ & 20.557 & 0.002 & lower \\
\hline Alpine meadow & $0.63 \pm 0.03$ & $0.60 \pm 0.02$ & 0.669 & 0.437 & ns \\
\hline Natural pioneer & $0.56 \pm 0.06$ & $0.39 \pm 0.02$ & 7.440 & 0.026 & higher \\
\hline Ruderal & $0.18 \pm 0.04$ & $0.03 \pm 0.01$ & 12.241 & 0.008 & higher \\
\hline
\end{tabular}

'See Figure 3 for a detailed definition. ${ }^{2}$ Proportion of species that can occur in a vegetation type 
(a) Long-term development (4 sites)

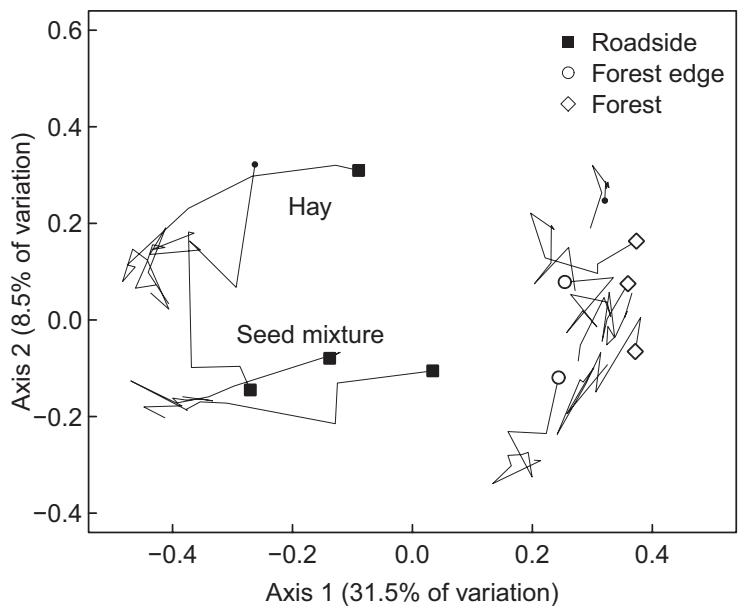

(b) Recent development (8 sites)

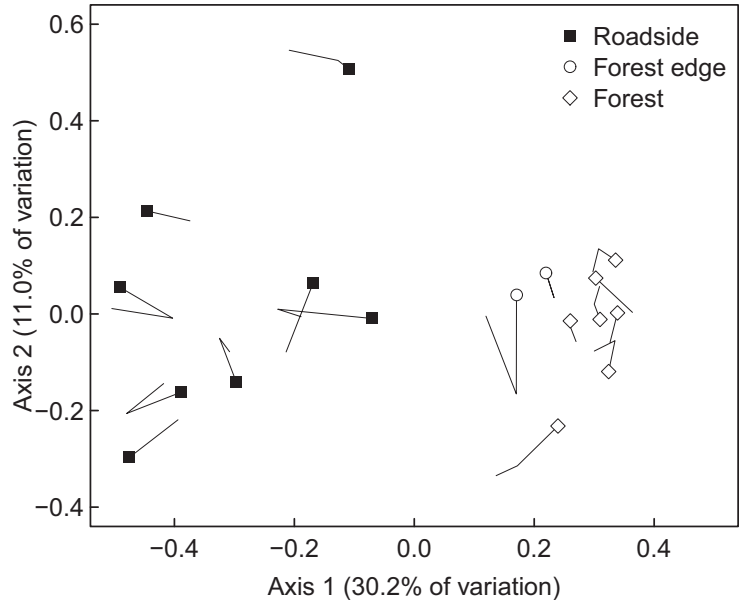

Figure 4 - Ordination plots from principal coordinates analysis illustrating changes in species composition in permanent plots on roadsides and in adjacent forests or forest edges. Final relevés (2010) are highlighted by symbols, except for two plots destroyed by a landslide (small dots = relevés from 1987). In both datasets, the first ordination axis separates roadside relevés from forest or forest edge relevés.

Ecological indicator values and ecological species groups

Roadsides initially had lower average ecological indicator values for continentality, and higher values for temperature, light, nutrients, soil moisture and salt tolerance, compared to forest or forest edge plots (Figure 6). These differences largely vanished between 1980 and 2002. Nevertheless, roadsides still had significantly higher indicator values for light and salt tolerance than forested relevés between 2002 and 2010 (Table 2b).
The proportion of forest species increased gradually on roadsides between 1969 and 2010 but remained significantly lower than in the forest relevés (Figure 7a, Table 2c). The proportion of alpine meadow species initially increased on roadsides and was higher than in forest relevés, but the difference disappeared subsequently (Figure 7b). The proportion of species from natural pioneer habitats strongly increased on roadsides between 1969 and 1983 and then slightly decreased, but it remained significantly higher than in forests (Figure 7c, Table 2c). The proportion of spe-

Table 3 - Species characteristic of roadside plots or forested plots (forest + forest edge), in the ordination of vegetation relevés from 1969-2010 (4 sites, 144 species) and from 2002-2010 (8 sites, 86 species). Species were regarded as characteristic of either plot type if they had scores beyond \pm 0.85 on the first axis of the respective ordination (Figure 4). Species with negative scores were characteristic of roadside plots, and species with positive scores were characteristic of forested plots.

\begin{tabular}{|c|c|c|c|}
\hline \multicolumn{2}{|c|}{ Species characteristic of roadside plots } & \multicolumn{2}{|c|}{ Species characteristic of forested plots } \\
\hline $\begin{array}{l}1969-2010 \\
\text { (Figure 4a) }\end{array}$ & \begin{tabular}{|l|}
$2002-2010$ \\
(Figure 4b)
\end{tabular} & \begin{tabular}{|l|}
$1969-2010$ \\
(Figure 4a)
\end{tabular} & \begin{tabular}{|l|}
$2002-2010$ \\
(Figure 4b)
\end{tabular} \\
\hline Achillea millefolium & & Calamagrostis varia & Calamagrostis varia \\
\hline Agrostis stolonifera & & Carex alba & Carex alba \\
\hline Alchemilla vulgaris & & Carex humilis & \\
\hline Bryum sp. & & Carex sempervirens & \\
\hline Campanula cochlearifolia & & Daphne striata & \\
\hline Carum carvi & & Erica carnea & Erica carnea \\
\hline Dactylis glomerata & & Hieracium murorum & \\
\hline Festuca ovina & Festuca ovina & Homogyne alpina & Homogyne alpina \\
\hline Festuca rubra & & Melampyrum pratense & Melampyrum pratense \\
\hline Pimpinella saxifraga & & Oxalis acetosella & \\
\hline Plantago alpina & & Polygala chamaebuxus & Polygala chamaebuxus \\
\hline Plantago lanceolata & & Rytidiadelphus sp. & Rytidiadelphus sp. \\
\hline Plantago media & & Sesleria caerulea & Sesleria caerulea \\
\hline Poa alpina & & Vaccinium vitis-idaea & Vaccinium vitis-idaea \\
\hline \multicolumn{4}{|l|}{ Taraxacum officinale } \\
\hline \multicolumn{4}{|l|}{ Trifolium pratense } \\
\hline & Hieracium pilosella & & \\
\hline & Hieracium staticifolium & & \\
\hline & Leontodon hispidus & & \\
\hline & Polygala amarella & & \\
\hline & Viola rupestris & & \\
\hline
\end{tabular}


(a) Between plots of the same type

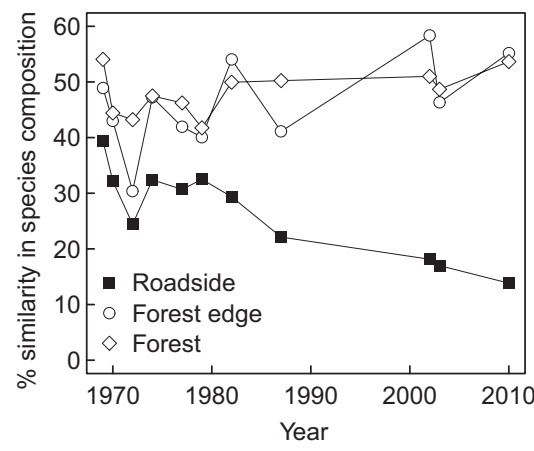

(b) Between plots of different types

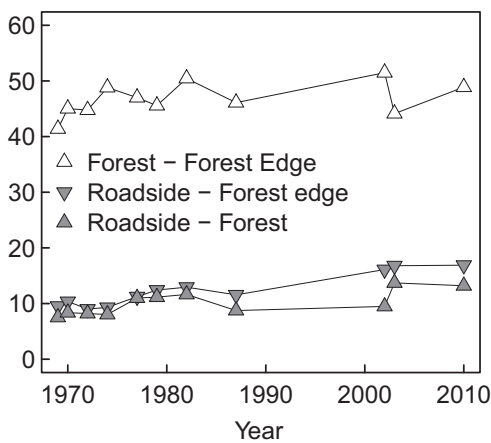

Figure 5 - Long-term changes in similarity of species composition between plots (1969-2010). Similarities were calculated as 1-Bray-Curtis distance index, (a) for all pairs of relevés belonging to the same plot type and (b) for all pairs of relevés belonging to different plot types. Graphs show means \pm s.e. per plot type (or combination of plot types) and year; $n=4$ (roadside), 2 (forest edge) and 3 (forest).

cies from ruderal habitats in the lowlands decreased sharply throughout the observation period (Figure 7d) but remained significantly higher than in the forests (Table 2c); ruderal species did not increase in the forests or on forest edges (Figure 7d).

\section{Discussion}

Replacement of sown species with local species

The first aim of this study was to monitor the fate of the species sown on the roadsides in 1968. Initially, most sown species occurred in some of the roadside plots but subsequently the average number of sown species per plot declined and still seems to be declining after 42 years. Thus, sown species could establish initially but most of them did not persist. Instead, roadsides were colonized by species from the surrounding natural vegetation, as reflected by an increasing proportion of forest species and species from natural pioneer habitats. Our second research question could therefore be answered positively, i.e. roadside development met the conservation aims of the SNP.

There was no evidence that sown species colonized the surrounding forest habitats and modified their species composition (third research question). This might have been expected because mountain pine forests along the Ofenpass road are open, with a meadowlike herb layer. High light availability in the understory usually promotes the establishment of roadside species in adjacent forests (Flory \& Clay 2009; Sharma \& Raghubanshi 2009). The absence of expansion may be due to a reduced vitality of the sown species on the roadsides (low seed production), together with low probability of survival of any seedlings germinating in the forest.

The observed species dynamics were probably driven by climatic and edaphic factors. Cut and fill slopes in mountain areas usually present rocky soils depleted of organic matter, with reduced nutrient availability and reduced water retention (Takahashi \& Miyajim 2010; Paiaro et al. 2011). These factors may be conducive to species establishment in an oceanic climate, as they reduce the competitiveness of fast-growing species and thus create niches for the recruitment of less competitive species (Tikka et al. 2000; de la Riva et al. 2011). Conversely, in a dry, continental climate, roadside soil properties exacerbate climatic stress and reduce both the development of vegetation cover and the species pool able to colonize these harsh habitats (Mola et al. 2011). The development of roadsides in the SNP therefore corresponds to that described from other areas with dry, continental climate, such as north-east Spain (Bochet et al. 2007) as well as boreal forests (Karim \& Mallik 2008).

Ecological indicator values illustrate the influence of climatic and edaphic factors on roadside development. Usually, changes in ecological indicator values are interpreted in terms of changes in site conditions, assuming that plant species composition is in equilibrium with site conditions (Diekmann 2003). In this case, however, initial species composition on roadsides was determined by sowing. Hence, changes in average indicator values mainly reflect the disappearance of the sown species together with colonization by species better adapted to local conditions (summer frosts, drought, high $\mathrm{pH}$ and low nutrient availability). The proportion of salt-tolerant species decreased over time even though salt was applied on the road (mainly after 1995), suggesting that salt stress was less decisive for species composition than climatic or edaphic stress (Brown \& Gorres 2011).

Besides habitat conditions, propagule availability is an essential determinant of spontaneous roadside colonization: the roadside flora is mainly recruited from species that occur in the neighbourhood (Tikka et al. 2000; Bochet et al. 2007; Mola et al. 2011) as well as species transported by cars (von der Lippe \& Kowarik 2007). In the SNP, roadside slopes are narrow (less than $10 \mathrm{~m}$ wide) and directly adjacent to mountain pine forest. Mountain pine (Pinus mugo) is a pioneer tree species and its dominance in this region results from intensive past forest exploitation (Risch et al. 2004; Risch et al. 2009). Its colonizing ability is visible in the naturally disturbed habitats, such as landslides, scree, 
(a) Temperature

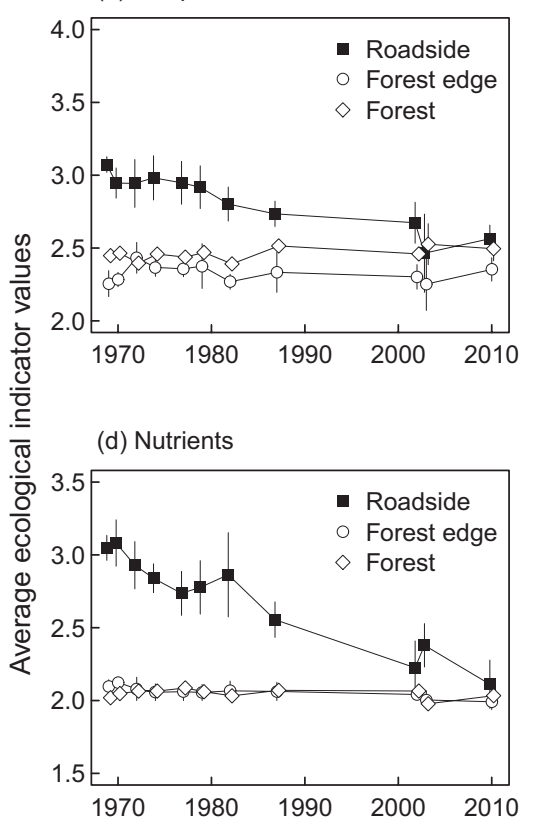

(b) Continentality

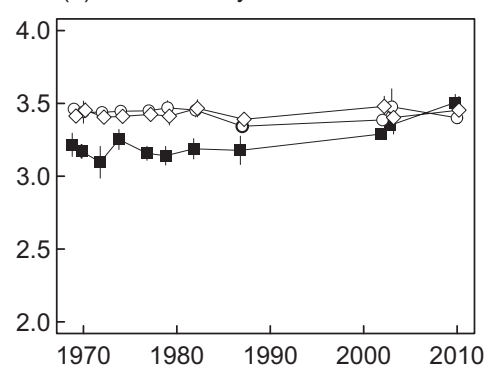

(e) Soil pH

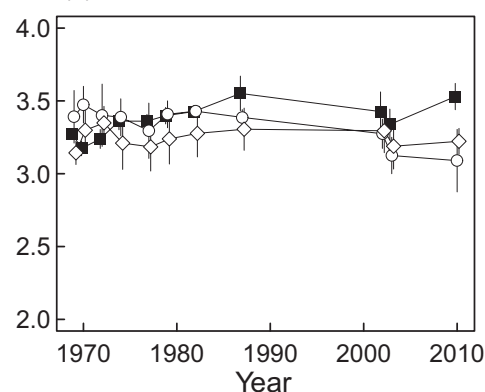

(c) Light

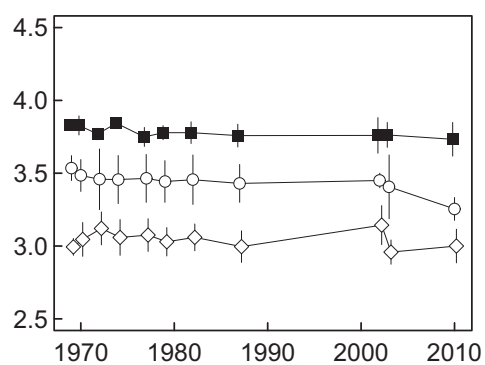

(f) Soil moisture

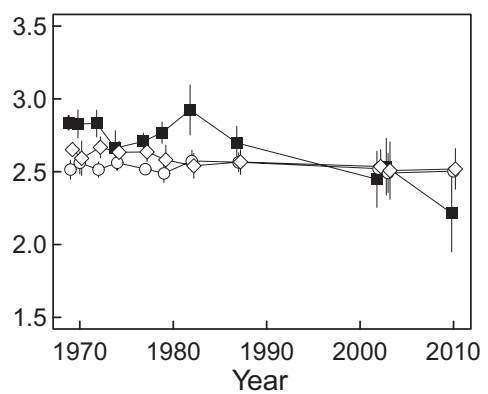

(g) Salt tolerance

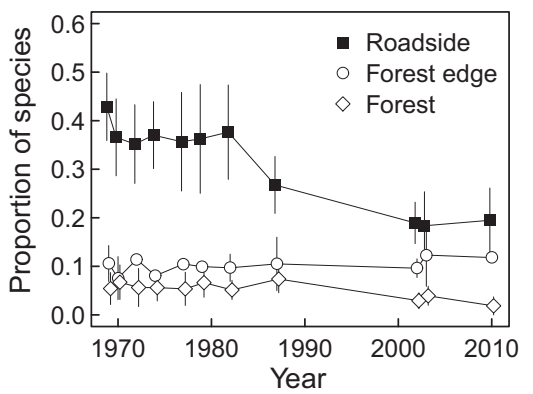

Figure 6 - Long-term changes in average ecological indicator values of the vegetation (1969-2010). Graphs show means \pm s.e. per plot type and year; $n=4$ (roadside), 2 (forest edge) and 3 (forest). While panels a-f represent weighted averages of the indicator values of species included in the relevé (see Methods section for calculations), panel g represents the proportion of species listed as salt-tolerant in Landolt (2010).

river slope cuts and riverbeds, all of which exhibit regeneration of pine (Figure 1c). The current vegetation structure and species composition of the roadsides thus reflects that of naturally disturbed habitats, with varying degrees of succession towards forest.

Effect of seeding procedure (seed mixture or hay transfer)

Two seed sources were used for seeding in 1968. At that time, botanists expected that hay transfer would lead to faster and more stable vegetation development because the hay, collected in the nearby Mustair valley, would probably contain more different species and genotypes better adapted to local conditions than seeds from more remote provenances (archives of the SNP). After 20 years, Klötzli (1991) indeed reported a higher vegetation cover and greater species richness in plots with hay application. The long-term development is difficult to evaluate in the present case because only two hay-transfer plots remained by 2010 . One of them had become similar to the standard seeded plots; the second plot remained different, but this site was exceptional due to its northern aspect and moist soil. Thus, greater cover and richness of the vegetation in this plot was probably due to more favourable site conditions and the seed source probably had only a small effect.

Similar results have been reported from other restoration experiments (reviewed by Kiehl et al. 2010). For example, on post-mining sites in eastern Germany, hay transfer was initially more successful in re-establishing species-rich grasslands than sowing of a seed mixture but the difference vanished over time (Baasch et al. 2012). On roadsides in Spain, a higher initial vegetation cover was obtained after hydroseeding native species as compared to commercial seed mixtures (Bochet et al. 2010). However, after several years, neither the standard seed mixture nor a mixture enriched with local species managed to establish due to the dry climate and poor topsoil quality (Mola et al. 2011), and the establishment rate of native species was independent of the seed mixture used initially (de la Riva et al. 2011). Accordingly, the improvement of soil conditions through topsoil application and the maintenance 
(a) Forest species

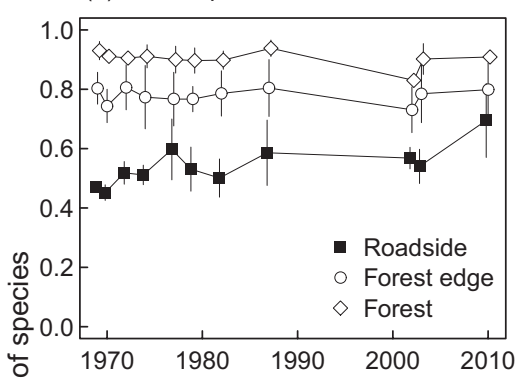

(c) Scree and alluvial species

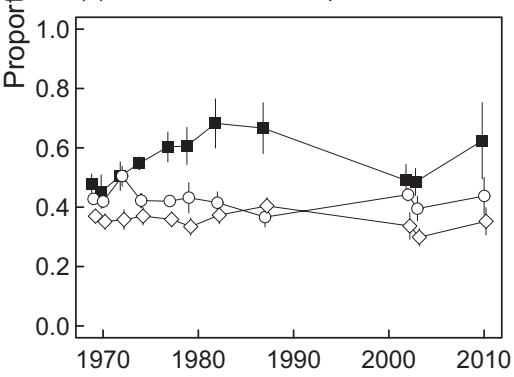

(b) Alpine meadow species

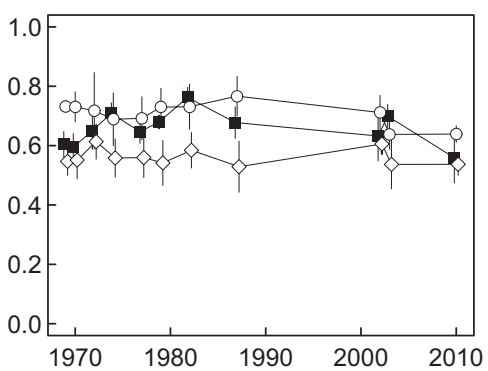

(d) Ruderal lowland species

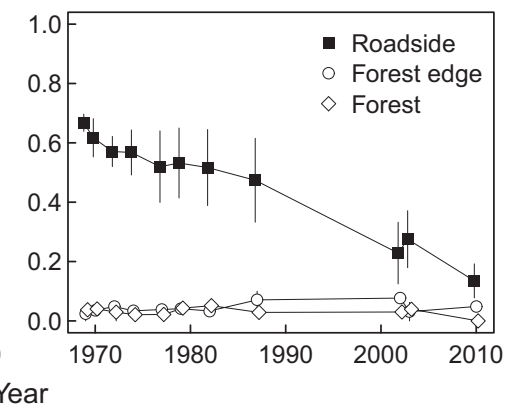

Figure 7 - Long-term changes in the affinity of the vegetation to four habitat types, as measured by the proportion of species or species aggregates that can occur in the respective habitat type according to Landolt (2010). Graphs show means \pm s.e. per plot type and year; $n=4$ (roadside), 2 (forest edge) and 3 (forest).

of native plant communities as seed sources close to the roads seemed to be most important for effective restoration (Matesanz et al. 2006; Brown \& Gorres 2011; Mola et al. 2011).

\section{No colonization by alien species}

Roads are known worldwide as starting points for invasions by alien species (Rentch et al. 2005; Pauchard \& Alaback 2006; von der Lippe \& Kowarik 2007; Sharma \& Raghubanshi 2009). Mountain roads moreover act as corridors along which lowland species (native or alien) can spread into higher elevations (Takahashi \& Miyajim 2010). Contrary to this general pattern, which led to our fourth research question, no alien species became established on the roadsides and the proportion of ruderal (lowland) species decreased over time throughout the study. Furthermore, no alien species or ruderal lowland species colonized the natural forests, i.e. they were neither recorded in the plots or surrounding area nor seen while walking along the road. In two surveys of car parks (severely disturbed areas) on mountain roads, only two alien species were found along the Ofenpass road (Matricaria discoidea and Senecio rupestris, Becker et al. 2005; Seipel 2011). Several reasons may account for this resistance to plant invasions.

First, the study area was located in the upper subalpine belt, near the timberline. Decreasing frequency of alien species with increasing elevation is a worldwide pattern (Alexander et al. 2011) which is also well established for Switzerland (Becker et al. 2005). The effect of altitude is exacerbated by the continental climate of the Central Alps, which implies severe winter frosts as well as the regular incidence of frost and drought during the growing season. Many alien species found along roadsides are annual or biennial species and the length of the growing season and / or minimal winter temperatures can be crucial for their ability to build populations (Trtikova et al. 2010).

Second, opportunities for dispersal of alien species along the Ofenpass road are limited by the fact that this road connects two remote subalpine regions without cities, crop fields or other extensive ruderal habitats likely to harbour source populations of alien species. Hence, cars are less likely to transport propagules of alien species into the SNP. The relevance of the large-scale landscape context for plant invasions along roads has been demonstrated in several other studies (e.g. Pauchard \& Alaback 2004; Foxcroft et al. 2011).

Finally, most alien species found along high-elevation mountain roads in other surveys were of Eurasian origin (Pauchard \& Alaback 2004; Pickering \& Hill 2007; Takahashi \& Miyajim 2010). Hence, a number of species classified as alien species in other surveys of mountain roads were recorded as native species in the present study (e.g. Achillea millefolium, Taraxacum officinale, Trifolium repens, Trifolium pratense, Plantago spp.). In a comparison of alien species richness along mountain roads in eight regions of the world, species numbers in Switzerland were lower than in all other (non-European) regions, probably for the same reason (Alexander et al. 2011). Overall, the SNP combines a number of factors reducing the risk of plant invasions and this probably led to the observed absence of alien plants along the Ofenpass road. 


\section{Conclusions}

- Forty-two years after road construction, the vegetation structure and species composition of roadsides in the SNP was similar to that of naturally disturbed habitats and a slow succession towards natural subalpine forest was ongoing.

- The sown grassland species disappeared progressively and were replaced by native species adapted to the local climate and soil. Sown species did not spread into natural habitats. This suggests that seeding of grassland species within protected subalpine forests is not necessarily problematic for conservation.

- No invasive alien species colonized the roadsides despite the long-term persistence of open soil. The rapid creation of a vegetation cover was not necessary to prevent plant invasions.

- The development of roadsides in the SNP was determined by harsh conditions created by a continental subalpine climate and poorly developed soils. Therefore, these conclusions may not hold for other Alpine regions with different geology and a more oceanic climate.

- After 42 years, the initial aim of this monitoring programme has been achieved. Monitoring should continue with a focus on invasive species and on the impact of salt treatment of the road during winter.

\section{Acknowledgements}

We thank the SNP management for long-term support of this research, particularly with the labelling of permanent plots and geographic data management. Field expenses were partly covered by the Research Committee of the Swiss National Park. Several friends and colleagues joined us during field work; we especially thank B. Allgöwer for her essential assistance. We further thank T. Scheurer for initiating the final survey and data analysis, as well as J. Alexander, T. Scheurer and two referees for valuable suggestions on drafts of the manuscript.

\section{References}

Aeschimann, D. \& C. Heitz 2005. Synonymie-Index der Schweizer Flora und der angrenzender Gebiete (SISF). Documenta Floristicae Helveticae 2: 1-323. http://www.crsf.ch/documents/download/x/ ISFS2_20051115.pdf.

Alexander, J.M., C. Kueffer, C.C. Daehler, P.J. Edwards, A. Pauchard, T. Seipel \& M. Consortium 2011. Assembly of nonnative floras along elevational gradients explained by directional ecological filtering. Proceedings of the National Academy of Sciences of the United States of America 108: 656-661.

Baasch, A., A. Kirmer \& S. Tischew 2012. Nine years of vegetation development in a postmining site: effects of spontaneous and assisted site recovery. Journal of Applied Ecology 49: 251-260.

Becker, T., H. Dietz, R. Billeter, H. Buschmann \& P.J. Edwards 2005. Altitudinal distribution of alien plant species in the Swiss Alps. Perspectives in Plant Ecology, Evolution and Systematics 7: 173-183.

Bochet, E., P. Garcia-Fayos \& J. Tormo 2007. Road slope revegetation in semiarid mediterranean environments. Part I: Seed dispersal and spontaneous colonization. Restoration Ecology 15: 88-96.

Bochet, E., J. Tormo \& P. García-Fayos 2010. Native species for roadslope revegetation: selection, validation, and cost effectiveness. Restoration Ecology 18: 656-663.

Brown, R.N. \& J.H. Gorres 2011. The use of soil amendments to improve survival of roadside grasses. Hortscience 46: 1404-1410.

de la Riva, E.G., M.A. Casado, M.D. Jiménez, I. Mola, M. Costa-Tenorio \& L. Balaguer 2011. Rates of local colonization and extinction reveal different plant community assembly mechanisms on road verges in central Spain. Journal of Vegetation Science 22: 292-302.

Diekmann, M. 2003. Species indicator values as an important tool in applied plant ecology - a review. Basic and Applied Ecology 4: 493-506.

Flory, S.L. \& K. Clay 2009. Effects of roads and forest successional age on experimental plant invasions. Biological Invasions 142: 2531-2537.

Foxcroft, L.C., V. Jarosik, P. Pysek, D.M. Richardson \& M. Rouget 2011. Protected-area boundaries as filters of plant invasions. Conservation Biology 25: 400-405.

Karim, M.N. \& A.U. Mallik 2008. Roadside revegetation by native plants I. Roadside microhabitats, floristic zonation and species traits. Ecological Engineering 32: 222-237.

Kiehl, K., A. Kirmer, T.W. Donath, L. Rasran \& N. Hölzel 2010. Species introduction in restoration projects - Evaluation of different techniques for the establishment of semi-natural grasslands in Central and Northwestern Europe Basic and Applied Ecology 11: 285-299.

Klötzli, F. 1991. Zum Einfluß von Straßenböschungsansaaten auf die umliegende naturnähere Vegetation am Beispiel des Schweizer Nationalparks. Laufener Seminarbeiträge 1991: 114-123.

Landolt, E., B. Bäumler, A. Erhardt, O. Hegg, F. Klötzli, W. Lämmler, M. Nobis, K. Rudmann-Maurer, F.H. Schweingruber, J.-P. Theurillat, E. Urmi, M. Vust \& T. Wohlgemuth 2010. Flora indicativa. Haupt. Bern.

Lauber, K. \& G. Wagner 2007. Flora Helvetica 4. ed. Haupt. Bern.

Matesanz, S., F. Valladares, D. Tena, M. Costa-Tenorio \& D. Bote 2006. Early dynamics of plant communities on revegetated motorway slopes from southern Spain: is hydroseeding always needed? Restoration Ecology 14: 297-307.

Mola, I., M.D. Jiménez, N. López-Jiménez, M.A. Casado \& L. Balaguer 2011. Roadside reclamation 
outside the revegetation season: management options under schedule pressure. Restoration Ecology 19: 83-92.

Paiaro, V., M. Cabido \& E. Pucheta 2011. Altitudinal distribution of native and alien plant species in roadside communities from central Argentina. Austral Ecology 36: 176-184.

Pauchard, A. \& P.B. Alaback 2004. Influence of elevation, land use, and landscape context on patterns of alien plant invasions along roadsides in protected areas of south-central Chile. Conservation Biology 18: 238-248.

Pauchard, A. \& P.B. Alaback 2006. Edge type defines alien plant species invasions along Pinus contorta burned, highway and clearcut forest edges. Forest Ecology and Management 223: 327-335.

Pickering, C. \& W. Hill 2007. Roadside weeds of the Snowy Mountains, Australia. Mountain Research and Development 27: 359-367.

Rentch, J.S., R.H. Fortney, S.L. Stephenson, H.S. Adams, W.N. Grafton \& J.T. Anderson 2005. Vegetation-site relationships of roadside plant communities in West Virginia, USA. Journal of Applied Ecology 42: 129-138.

Risch, A.C., M. Schütz \& H. Bugmann 2009. Predicting long-term development of abandoned subalpine conifer forests in the Swiss National Park. Ecological Modelling 220: 1578-1585.

Risch, A.C., M. Schütz, B.O. Krüsi, F. Kienast, O. Wildi \& H. Bugmann 2004. Detecting successional changes in long-term empirical data from subalpine conifer forests. Plant Ecology 172: 95-105.

Seipel, T.F. 2011. Distribution and demographics of nonnative plants in mountainous regions. PhD Thesis No. 20031. ETH Zurich. Zurich.

Sharma, G.P. \& A.S. Raghubanshi 2009. Plant invasions along roads: a case study from central highlands, India. Environmental Monitoring and Assessment 157: 191198.

Takahashi, K. \& Y. Miyajim 2010. Effects of roads on alpine and subalpine plant species distribution along an altitudinal gradient on Mount Norikura, central Japan. Journal of Plant Research 123: 741-749.

Tikka, P., P. Koski, R. Kivelà \& M. Kuitunen 2000. Can grassland plant communities be preserved on road and railway verges? Applied Vegetation Science 3: 25-32.

Trtikova, M., P.J. Edwards \& S. Güsewell 2010. No adaptation to altitude in the invasive plant Erigeron annuus in the Swiss Alps. Ecography 33: 556-564.

von der Lippe, M. \& I. Kowarik 2007. Long-distance dispersal of plants by vehicles as a driver of plant invasions. Conservation Biology 21: 986-996.

\section{Authors}

\section{Sabine Güsewell}

Lecturer in plant ecology at ETH Zurich, and lecturer in statistics at Berne University of Applied Sciences. Research topics: plant communities, invasive plants, plant-soil interactions. Institute of Integrative Biology, ETH Zurich, Switzerland.

email: sabine.guesewell@env.ethz.ch.

\section{Frank Klöłzli}

Professor emeritus in plant ecology at ETH Zurich (Geobotanical Institute). Research topics: European and worldwide vegetation classification, vegetation limits, long-term vegetation dynamics, grazing, vegetation management.

email: fl_kloetzli@bluewin.ch 